\title{
Micropropagation and Microrhizome Induction in Costus pictus D. Don Using In Vitro and Ex Vitro Nodal Segments as Explant
}

\author{
Kshetrimayum PUNYARANI*, Jitendra G. SHARMA \\ Manipur University, Department of Life Sciences, Imphal-795003, India; punyaraniksh@gmail.com (*corresponding author)
}

\begin{abstract}
Costus pictus D. Don is a potent anti-diabetic plant used in folk, ayurvedic and homeopathic system of medicine. Gene and protein expression of key targets in insulin signaling pathway have revealed that methyl tetracosonoate, a bio-active molecule from Costus pictus extract has anti-diabetic activity. The axillary buds of Costus pictus are dormant. The dormancy of axillary buds were broken when cultured in Murashige and Skoog (MS) medium supplemented with 3-4 $\mu \mathrm{M}$ 6-benzylaminopurine (BAP) in combination with 0.2 $1 \mu \mathrm{M}$ naphthalene acetic acid (NAA). The highest bud-break percentage was achieved in those supplemented with $0.6 \mu \mathrm{M}$ NAA and $3 \mu \mathrm{M}$ BAP. The sprouted axillary buds were transferred onto medium supplemented with $0.6 \mu \mathrm{M}$ NAA and 6-10 $\mu \mathrm{M}$ BAP for shoot multiplication. The maximum average number of shoot was achieved in medium supplemented with $0.6 \mu \mathrm{M}$ NAA and $8 \mu \mathrm{M}$ BAP. The shoots were successfully rooted when transferred onto media supplemented with 1-12 $\mu \mathrm{M}$ NAA or indole-3-acetic acid (IAA) and $3 \mu \mathrm{M}$ BAP. The maximum number of roots was found in $8 \mu \mathrm{M}$ NAA and $3 \mu \mathrm{M}$ BAP. The dormancy of in vitro axillary buds were also successfully broken in stems from which shoot apex were decapitated and cultured in MS medium with $0.6 \mu \mathrm{M}$ NAA, 7 $\mu \mathrm{M}$ BAP and 5-13\% sucrose. These sprouted in vitro axillary buds could be used as secondary explants for shoot multiplication. The maximum was in medium supplemented with 9\% sucrose. Rhizomes were successfully induced when 4-month old plantlets were cultured on $1 / 2$ strength MS medium supplemented with $2.4 \mu \mathrm{M}$ NAA, $32 \mu \mathrm{M}$ BAP and 5-13\% sucrose. Microrhizomes formed in 9\% sucrose was largest in size with highest average fresh weight.
\end{abstract}

Keywords: anti-diabetic, bud-break, Costus pictus, microrhizomes, nodal segments

Abbreviations: AdS-Adenine Sulphate, ABA-Abscissic acid, BAP-6-Benzylaminopurine, IAA-Indole-3-acetic acid, MS-Murashige and Skoog, NAA-Naphthalene acetic acid, PGR-Plant growth regulator

\section{Introduction}

The genus Costus Linn. belongs to the family Costaceae. It has been separated from the family Zingiberaceae on the basis of the presence of spirally arranged leaves and rhizomes being free from aromatic essential oils. Kirchoff and Rutishauser (1990) suggested that Costaceae could be distinguished from other families within the order Zingiberales by well-developed and sometimes branched aerial shoots that have characteristic monostichous (one-sided) spiral phyllotaxy. Molecular and morphological data analysed in a phylogenetic framework suggested a single origin of Costaceae (Kress, 1990, 1995; Kress et al., 2001; Specht et al., 2001; Specht, 2006) supporting earlier investigations that suggested the separation of Costaceae and Zingiberaceae. Costuspictus D. Don syn. Costus mexicanus (DC.) commonly known as spiral ginger, step ladder or insulin plant is a plant originated in Mexico. It is a potent anti-diabetic plant and used in folk, ayurvedic and homeopathic systems of medicine (Joshi, 2000). It is also used in asthma, eye complaints and snake bite. Eighteen chemicals have been analyzed and identified from the leaves of Costus pictus (George et al., 2007). Gene and protein expression of key targets in insulin signal- ing pathway have revealed that methyl tetracosonoate, a bio-active molecule isolated from Costus pictus extract has anti-diabetic activity (Shilpa et al., 2009). Jayasri et al. (2009) reported that Costus pictus extract have inhibitory effect on carbohydrate hydrolysing enzyme like $\alpha$-glucosidase and $\alpha$-amylase. These findings have revealed anti-diabetic potential of Costus pictus. Geerish $e t$ al. (2009) suggested that glucose lowering effect of Costus pictus was associated with the potentiation of insulin release from pancreatic islets and peripheral utilization of glucose. However, the existence of this species has been threatened due to deforestation, jhum cultivation, habitat disturbance for conversion of wetland ecosystem into agricultural land and uncontrolled plucking/uprooting. Micropropagation through rhizomatous eyes/ buds/ shoot tips or rhizome thin sections has disadvantages: the uprooted rhizomes usually fail to survive after rhizomatous eyes/ shoot tips are decapitated, and establishment of in vitro culture is usually difficult due to higher contamination. The present investigation, therefore, is an attempt to develop mass propagation protocol using nodal segments of stem. Micropropagation using nodal segments overcome many disadvantages of rhizomatous eye/ bud/ shoot tip culture. In nodal segment culture, contamination is less, 
mature stem which have produced seeds are used and one mature stem usually contain 15-20 axillary buds in comparison to 4-5 rhizomatous eyes in one rhizome. Shoot multiplication in Costus speciosus has been achieved using shoot tips (Chaturvedi et al., 1984), rhizome thin section (Malabadi et al., 2005) and nodal segment (Punyarani and Sharma, 2009). No report on in vitro regeneration of Costus pictus have been found. Hence, an efficient protocol for mass multiplication of Costus pictus has been developed.

\section{Materials and methods}

The stems were collected from the Experimental Field, Manipur University and washed under running tap water for $10 \mathrm{~min}$. Surface sterilization of nodal segments were done by treating with $0.1 \% \mathrm{HgCl}_{2}$ for $10 \mathrm{~min}$. Sterilization was followed by rinsing 3-4 times with sterile distilled water. The nodal segments were cultured in MS (Murashige and Skoog, 1962) medium supplemented with various plant growth regulators (PGRs), sucrose and $8 \mathrm{~g} \mathrm{~L}^{-1}$ agar. The $\mathrm{pH}$ of the media was adjusted to 5.8 before being autoclaved at $121^{\circ} \mathrm{C}$ for $20 \mathrm{~min}$ and $15 \mathrm{lbs} \mathrm{sq}$ inch $^{-1}$ pressure. All cultures were incubated at $25 \pm 2^{\circ} \mathrm{C}$ under $16 \mathrm{hr}$ (day/ night) photoperiod with light supplied by white fluorescent tubes (3000 Lux). Subculturing was carried out after every 4 weeks by trimming-off leaves and roots.

\section{Bud-break of Costus pictus}

MS media supplemented with 3-4 $\mu \mathrm{M}$ BAP in combination with $0.2-1 \mu \mathrm{M}$ NAA and $3 \%$ sucrose were tested in case of Costus pictus. Ten replicates were taken for the above experiments and repeated twice.

\section{Shoot multiplication and rooting of Costus pictus}

The sprouted buds from bud-break medium of Costus pictus were excised and subcultured in MS medium supplemented with 3-6\% sucrose in combination with $0.6 \mu \mathrm{M}$ NAA and 3-4 $\mu \mathrm{M}$ BAP or $0.6 \mu \mathrm{M}$ NAA in combination with 6-10 $\mu \mathrm{M}$ BAP and 5\% sucrose. The shoots of Costus pictus were subcultured in $3 \mu \mathrm{M}$ BAP and 1-12 $\mu \mathrm{M}$ NAA or IAA for rooting. 10 replicates were taken for the above experiments and repeated twice.

\section{Breaking of in vitro axillary bud dormancy}

Plantlets of Costus pictus (one month-old) from which shoot apex has been decapitated were transferred on to media supplemented with $0.6 \mu \mathrm{M}$ NAA, $7 \mu \mathrm{M}$ BAP and $5-13 \%$ sucrose for axillary bud sprout induction experiment. 10 replicates were taken for the above experiments and repeated twice.

\section{In vitro micro-rhizome induction}

Costus pictus plantlets ( 4 months-old) were transferred to $1 / 2$ strength MS media supplemented with $2.4 \mu \mathrm{M}$ NAA, $32 \mu \mathrm{M}$ BAP and $6-14 \%$ sucrose. Ten replicates were taken for the above experiments.

\section{Statistical analysis}

All the data were scored after 4 weeks. Data were analysed for significance using ANOVA and the differences contrasted using Tukey's comparison tests at 5\% probability test. All statistical analysis were performed using the SPSS statistical software package.

\section{Results}

\section{Initiation of nodal segment bud culture}

Stems collected during the month of April-September (temp. $22-27^{\circ} \mathrm{C}, \mathrm{RH}$ 60-80\%, Rainfall 100-210 mm) were suitable for axillary bud-break experiment. Stems collected during April-September showed bud-break within 4-5 days but those collected during October-December (temp. 18-22 ${ }^{\circ} \mathrm{C}$, RH 50-80\%, rainfall 50-100 mm) showed budbreak after 10-15 days. The stems stored at room temperature for 2-3 weeks prior to culturing without removing the leaf-sheath showed bud-break frequency significantly not different from those cultured on the same day of collection. However, bacterial contamination was higher than those cultured on the same day of collection. Stems from which leaf-sheath were removed and stored showed a low frequency of bud-break along with high percentage of bacterial contamination. Cut pieces stored at room temperature for more than 2-3 days usually lost its viability and contamination percentage was also high. It was observed that the nodal segments from the upper portion of stem showed higher percentage of bud-break (data not shown). Single nodal segments were cultured on MS medium alone and 3 or $5 \mu \mathrm{M}$ BAP in combination with $0.2-1 \mu \mathrm{M}$ NAA. The highest bud-break frequency (93.33\%) was achieved in those supplemented with $0.6 \mu \mathrm{M}$ NAA and $3 \mu \mathrm{M}$ BAP (Tab. 1, Fig. 1a).

\section{Shoot multiplication from single nodal segment culture}

\section{Effect of sucrose}

The sucrose concentration had direct effect on the growth and multiplication of culture. The buds which had

Tab. 1. Effect of MS medium supplemented with BAP and NAA on bud-break frequency in the culture of single node segment culture of Costus pictus

\begin{tabular}{cc}
\hline Treatment $(\mu \mathrm{M})$ & Bud-break $(\%)$ \\
\hline 0 & 23 \\
\hline $0.2 \mathrm{NAA}+3 \mathrm{BAP}$ & 66.67 \\
\hline $0.4 \mathrm{NAA}+3 \mathrm{BAP}$ & 76.67 \\
\hline $0.6 \mathrm{NAA}+3 \mathrm{BAP}$ & 93.33 \\
\hline $0.8 \mathrm{NAA}+3 \mathrm{BAP}$ & 80 \\
\hline 1 NAA + 3 BAP & 70 \\
\hline $0.2 \mathrm{NAA}+4 \mathrm{BAP}$ & 60 \\
\hline $0.4 \mathrm{NAA}+4 \mathrm{BAP}$ & 73.33 \\
$0.6 \mathrm{NAA}+4 \mathrm{BAP}$ & 86.67 \\
$0.8 \mathrm{NAA}+4 \mathrm{BAP}$ & 76.67 \\
$1 \mathrm{NAA}+4 \mathrm{BAP}$ & 66 \\
\hline
\end{tabular}


74

Tab. 2. In vitro induction of shoot multiplication of Costus pictus from single node segment in MS medium supplemented with different concentration of sucrose along with $0.6 \mu \mathrm{M}$ $\mathrm{NAA}+3 \mu \mathrm{M}$ BAP or $0.6 \mu \mathrm{M} \mathrm{NAA}+4 \mu \mathrm{M} \mathrm{BAP}$

\begin{tabular}{|c|c|c|}
\hline \multicolumn{2}{|c|}{ Sucrose concentration (\%) } & \multirow{2}{*}{$\begin{array}{l}\text { No. of shoots } \\
\text { (mean } \pm \text { S.E.) }\end{array}$} \\
\hline $0.6 \mathrm{NAA}+3 \mathrm{BAP})$ & $(0.6 \mathrm{NAA}+4 \mathrm{BAP})$ & \\
\hline 3 & & $1.00^{\mathrm{a}} \pm 0.26$ \\
\hline 4 & & $1.40^{\mathrm{a}} \pm 0.24$ \\
\hline 5 & & $2.80^{\mathrm{b}} \pm 0.20$ \\
\hline 6 & & $1.70^{\mathrm{a}} \pm 0.35$ \\
\hline & 3 & $1.90^{\mathrm{a}} \pm 0.22$ \\
\hline & 4 & $2.40^{\mathrm{a}} \pm 0.17$ \\
\hline & 5 & $3.70^{\mathrm{ab}} \pm 0.21$ \\
\hline & 6 & $2.10^{a} \pm 0.26$ \\
\hline
\end{tabular}

Means followed by same letters are not significantly different at $p<0.05$, according to Tukey's comparison test

Tab. 3. Effect of $0.6 \mu \mathrm{M}$ NAA in combination with different concentration of BAP on shoot multiplication of Costus pictus from single nodes segment in MS medium

\begin{tabular}{ccc}
\hline $\begin{array}{c}\text { Treatment with } \\
\text { BAP }(\mu \mathrm{M})\end{array}$ & $\begin{array}{c}\text { No. of shoots } \\
(\text { mean } \pm \text { S.E. })^{\mathrm{a}}\end{array}$ & $\begin{array}{c}\text { Shoots length }(\mathrm{cm}) \\
(\text { mean } \pm \text { S.E. })^{\mathrm{a}}\end{array}$ \\
\hline 6 & $6.10^{\mathrm{a}} \pm 0.39$ & $2.79^{\mathrm{a}} \pm 0.23$ \\
7 & $7.50^{\mathrm{ab}} \pm 0.22$ & $3.38^{\mathrm{a}} \pm 0.28$ \\
8 & $8.50^{\mathrm{ab}} \pm 0.26$ & $4.70^{\mathrm{a}} \pm 0.26$ \\
9 & $7.50^{\mathrm{ab}} \pm 0.22$ & $3.90^{\mathrm{a}} \pm 0.31$ \\
10 & $6.70^{\mathrm{a}} \pm 0.30$ & $3.00^{\mathrm{a}} \pm 0.42$ \\
\hline
\end{tabular}

${ }^{2}$ Means followed by same letters are not significantly different at $p<0.05$, according to Tukey's comparison test

grown upto suitable sizes were excised and sub-cultured on MS media supplemented with different concentration of sucrose in combination with $0.6 \mu \mathrm{M}$ NAA and 3 or $5 \mu \mathrm{M}$ BAP. The optimum concentration of sucrose for initiation of shoot multiplication was $5 \%$ sucrose with the average of 3.70 $\pm 0.21(0.6 \mu \mathrm{M} \mathrm{NAA}+5 \mu \mathrm{M} \mathrm{BAP})$ and $2.80 \pm 0.17$ $(0.6 \mu \mathrm{M} \mathrm{NAA}+3 \mu \mathrm{M}$ BAP) after 2 weeks (Tab. 2, Fig. $1 b)$. In all the further experiments, $5 \%$ sucrose concentration was used.

\section{Effect of auxins and cytokinins}

The axillary buds which had grown up to suitable sizes were excised and transferred to MS media supplemented with cytokinins and auxins. The excised buds differentiated to shoots within 1 week. Swelling occurred at the base of excised buds within 2-3 days. When the data were scored after 4 weeks, the best response for multiple shoots per explants was achieved in 0.6 $\mu \mathrm{M}$ NAA and 6-10 $\mu \mathrm{M}$ BAP (Tab. 3). The maximum average number of shoot $(8.50 \pm 0.26)$ was achieved in those supplemented with 0.6 $\mu \mathrm{M}$ NAA and $8 \mu \mathrm{M}$ BAP followed by $0.6 \mu \mathrm{M}$ NAA and 7 $\mu \mathrm{M}$ BAP (Tab. 3, Fig. 1c).

\section{In vitro rooting}

The shoots were successfully rooted when transferred onto medium supplemented with 1-12 $\mu \mathrm{M}$ NAA or IAA and $3 \mu \mathrm{M}$ BAP (Tab. 4). After 2 weeks on $12 \mu \mathrm{M}$ NAA and $3 \mu \mathrm{M}$ BAP supplemented medium induction of roots and multiple shoots along with callusing was observed. The roots were hairy and short. The maximum average number medium after 4 weeks is shown in Tab. 4 . The maximum average number of roots was $19.50 \pm 0.25$ in 8 $\mu \mathrm{M}$ IAA and $3 \mu \mathrm{M}$ BAP (Tab. 4, Fig. 1d). The plantlets on IAA and BAP supplemented media had longer shoots and roots than those from NAA and BAP (Tab. 4, Fig. 1d). The maximum average length of roots in IAA and BAP supplemented medium, was $8.45 \pm 0.14 \mathrm{~cm}$, wheareas it was $4.02 \pm 0.13 \mathrm{~cm}$ in NAA and BAP supplemented medium (Tab. 4). It was observed that the average number of multiple shoot decreased as the concentration of auxin increased. The maximum average number of shoots $(5.30 \pm 0.15)$ was achieved in $1 \mu \mathrm{M}$ NAA and $3 \mu \mathrm{M}$ BAP supplemented medium (Tab. 4). However, the average shoot and root length increased as the concentration of IAA was increased from 1-8 $\mu \mathrm{M}$. The maximum average shoot length $(8.24 \pm 0.13 \mathrm{~cm})$ and root length $(8.45 \pm 0.14$ $\mathrm{cm}$ ) was achieved in $8 \mu \mathrm{M}$ IAA and $3 \mu \mathrm{M}$ BAP (Tab. 4).

\section{In vitro axillary buds}

The dormancy of in vitro axillary buds were successfully broken when stems from which shoot apex were de-

Tab. 4. Effect of $3 \mu \mathrm{M}$ BAP in combination with different concentration of NAA and IAA on rooting and shoot multiplication of Costus pictus in MS medium

\begin{tabular}{|c|c|c|c|c|c|}
\hline \multicolumn{2}{|c|}{ Treatment $(\mu \mathrm{M})$} & \multirow{2}{*}{$\begin{array}{l}\text { No. of shoots } \\
\text { (mean } \pm \text { S.E.) }\end{array}$} & \multirow{2}{*}{$\begin{array}{l}\text { Length of the shoots }(\mathrm{cm}) \\
(\text { mean } \pm \text { S.E. })^{\mathrm{a}}\end{array}$} & \multirow{2}{*}{$\begin{array}{l}\text { No. of roots } \\
(\text { mean } \pm \text { S.E. })^{a}\end{array}$} & \multirow{2}{*}{$\begin{array}{l}\text { Length of the roots }(\mathrm{cm}) \\
(\text { mean } \pm \text { S.E. })^{\mathrm{a}}\end{array}$} \\
\hline NAA & IAA & & & & \\
\hline 1 & & $5.30^{\mathrm{b}} \pm 0.15$ & $2.06^{a} \pm 0.34$ & $20.90^{\mathrm{a}} \pm 0.70$ & $2.27^{\mathrm{a}} \pm 0.27$ \\
\hline 4 & & $4.50^{b} \pm 0.22$ & $3.17^{\mathrm{ab}} \pm 0.28$ & $23.10^{\mathrm{a}} \pm 0.52$ & $3.26^{\mathrm{b}} \pm 0.11$ \\
\hline 8 & & $3.50^{\mathrm{ab}} \pm 0.22$ & $2.28^{a} \pm 0.28$ & $25.70^{\mathrm{b}} \pm 0.21$ & $4.02^{\mathrm{ab}} \pm 0.13$ \\
\hline \multirow[t]{5}{*}{12} & & $2.30^{a} \pm 0.27$ & $1.55^{a} \pm 0.25$ & $22.80^{\mathrm{a}} \pm 0.65$ & $3.15^{\mathrm{b}} \pm 0.20$ \\
\hline & 1 & $3.50^{\mathrm{ab}} \pm 0.22$ & $6.68^{a} \pm 0.13$ & $16.10^{a} \pm 0.34$ & $7.05^{\mathrm{a}} \pm 0.14$ \\
\hline & 4 & $2.30^{\mathrm{b}} \pm 0.21$ & $6.83^{a} \pm 0.13$ & $17.50^{\mathrm{b}} \pm 0.54$ & $7.64^{b} \pm 0.17$ \\
\hline & 8 & $1.10^{\mathrm{a}} \pm 0.28$ & $8.24^{\mathrm{ab}} \pm 0.13$ & $19.50^{\mathrm{ab}} \pm 0.25$ & $8.45^{\mathrm{ab}} \pm 0.14$ \\
\hline & 12 & $1.20^{\mathrm{a}} \pm 0.29$ & $7.62^{\mathrm{b}} \pm 0.12$ & $17.80^{\mathrm{b}} \pm 0.40$ & $7.57^{\mathrm{b}} \pm 0.15$ \\
\hline
\end{tabular}

${ }^{a}$ Means followed by same letters are not significantly different at $p<0.05$, according to Tukey's comparison test 


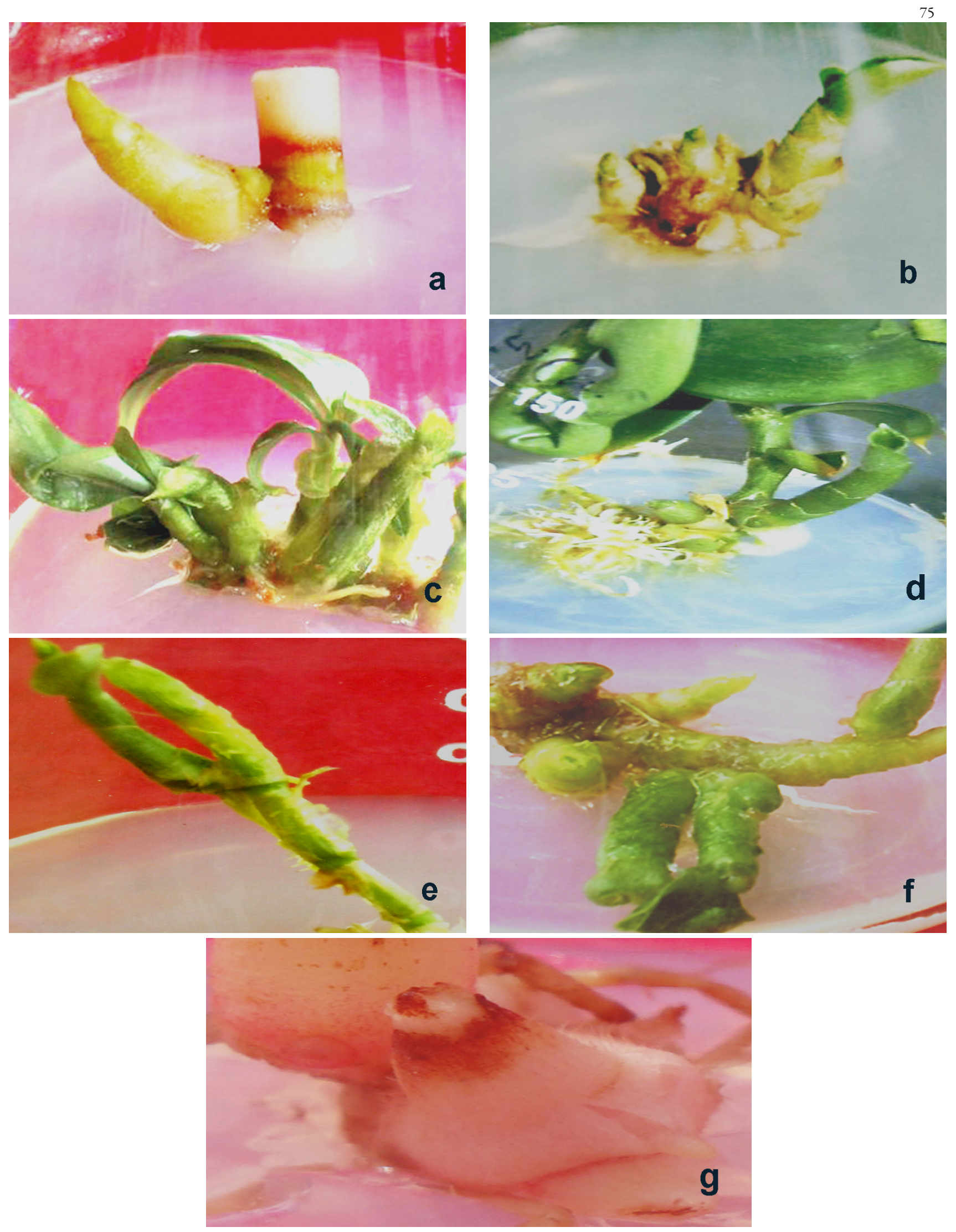

Fig. 1. Micropropagation of Costus pictus, (a) axillary bud sprouting from single node segments in MS + $3 \mu \mathrm{M}$ BAP $+0.6 \mu \mathrm{M}$ NAA, (b) axillary shoot proliferation in $\mathrm{MS}+5 \mu \mathrm{M}$ BAP $+0.6 \mu \mathrm{M} \mathrm{NAA}+5 \%$ sucrose, (c) axillary shoot proliferation in MS $+8 \mu \mathrm{M}$ BAP $+0.6 \mu \mathrm{M}$ NAA, (d) axillary shoot proliferation and rooting in $\mathrm{MS}+3 \mu \mathrm{M} \mathrm{BAP}+8 \mu \mathrm{M}$ IAA, (e) axillary bud sprout in $\mathrm{MS}+7 \mu \mathrm{M}$ $\mathrm{BAP}+0.6 \mu \mathrm{M}$ NAA $+7 \%$ sucrose, (f) axillary bud sprout in $\mathrm{MS}+7 \mu \mathrm{M} \mathrm{BAP}+0.6 \mu \mathrm{M}$ NAA $+9 \%$ sucrose, (g) Microrhizome induction of in $1 / 2 \mathrm{MS}+2.4 \mu \mathrm{M} \mathrm{NAA}+32 \mu \mathrm{M} \mathrm{BAP}+9 \%$ sucrose 
76

Tab. 5. Response of in vitro stem on MS medium supplemented $0.6 \mu \mathrm{M}$ NAA $+7 \mu \mathrm{M}$ BAP in combination with different concentration sucrose

\begin{tabular}{cccc}
\hline $\begin{array}{c}\text { Treatment } \\
\text { with } \\
\text { sucrose }(\%)\end{array}$ & Response & $\begin{array}{c}\text { No. of axillary } \\
\text { buds } \\
(\text { mean } \pm \text { S.E. })^{\mathrm{a}}\end{array}$ & $\begin{array}{c}\text { Length of axillary } \\
\text { buds }(\mathrm{cm}) \\
(\text { mean } \pm \text { S.E. })^{\mathrm{a}}\end{array}$ \\
\hline 5 & $\begin{array}{c}\text { Axillary bud } \\
\text { sprouted } \\
\text { along with } \\
\text { roots }\end{array}$ & $0.83^{\mathrm{a}} \pm 0.17$ & $1.07^{\mathrm{a}} \pm 0.10$ \\
7 & $\begin{array}{c}\text { Axillary bud } \\
\text { sprouted }\end{array}$ & $1.67^{\mathrm{a}} \pm 0.49$ & $2.55^{\mathrm{b}} \pm 0.28$ \\
9 & $\begin{array}{c}\text { Axillary bud } \\
\text { sprouted }\end{array}$ & $3.30^{\mathrm{b}} \pm 0.31$ & $2.91^{\mathrm{b}} \pm 0.08$ \\
11 & $\begin{array}{c}\text { Axillary bud } \\
\text { sprouted }\end{array}$ & $1.50^{\mathrm{a}} \pm 0.34$ & $3.63^{\mathrm{ab}} \pm 0.11$ \\
\hline & $\begin{array}{c}\text { Axillary bud } \\
\text { sprouted }\end{array}$ & $0.67^{\mathrm{a}} \pm 0.21$ & $2.81^{\mathrm{b}} \pm 0.14$ \\
\hline
\end{tabular}

${ }^{\mathrm{a}}$ Means followed by same letters are not significantly different at $p<0.05$, according to Tukey's comparison test

Tab. 6. Effect of $1 \frac{1}{2}$ strength MS medium supplemented with $2.40 \mu \mathrm{M}$ NAA and $32 \mu \mathrm{M}$ BAP and different concentration of sucrose on microrhizomes induction of $C$. pictus

\begin{tabular}{ccc}
\hline $\begin{array}{c}\text { Concentration } \\
\text { of sucrose }(\%)\end{array}$ & $\begin{array}{c}\text { Number of } \\
\text { microrhizomes } \\
(\text { mean } \pm \text { S.E. })^{\mathrm{a}}\end{array}$ & $\begin{array}{c}\text { Fresh weight of } \\
\text { rhizomes }(\mathrm{g}) \\
(\text { mean } \pm \text { S.E. })^{\mathrm{a}}\end{array}$ \\
\hline 5 & $0.60^{\mathrm{a}} \pm 0.16$ & $2.34^{\mathrm{a}} \pm 0.23$ \\
7 & $1.20^{\mathrm{a}} \pm 0.20$ & $3.32^{\mathrm{b}} \pm 0.22$ \\
9 & $1.70^{\mathrm{b}} \pm 0.15$ & $5.12^{\mathrm{ab}} \pm 0.11$ \\
11 & $1.40^{\mathrm{b}} \pm 0.16$ & $4.71^{\mathrm{ab}} \pm 0.10$ \\
\hline 13 & $1.10^{\mathrm{a}} \pm 0.10$ & $3.57^{\mathrm{b}} \pm 0.11$ \\
\hline
\end{tabular}

${ }^{a}$ Means followed by same letters are not significantly different at $p<0.05$,

according to Tukey's comparison test

capitated and cultured on media supplemented with $7 \mu \mathrm{M}$ BAP, $0.6 \mu \mathrm{M}$ NAA and 5-13\% sucrose before transferring to root induction medium (Tab. 5). The shoot from which shoot apex was decapitated showed longer axillary bud. The optimal concentration was $9 \%$ sucrose with an average number of axillary bud of $3.30 \pm 0.31$ within 4 weeks (Tab. 5, Fig. 1f). Increase in axillary bud sprout length was achieved as the concentration of sucrose increased. However, $13 \%$ sucrose was inhibitory as the length was decreased to $2.81 \pm 0.14 \mathrm{~cm}$ after achieving maximum length of $3.63 \pm 0.11 \mathrm{~cm}$ on $11 \%$ sucrose supplemented medium (Tab. 5). On medium supplemented with 5 and $7 \%$ sucrose, adventitious rooting of axillary bud was observed (Fig. 1e). Elongation of plantlets was observed along with axillary bud sprout, however, induction of roots was observed only on $7 \%$ sucrose supplemented media. The axillary shoots multiplied when decapitated and transferred on to shoot multiplication medium. The average number of shoots was not significantly different from that of ex vitro axillary buds (data not shown).

\section{Microrbizome induction}

The 4 month-old rooted microshoots were subcultured on media supplemented with 6-16\% sucrose, $0.6 \mu \mathrm{M}$ NAA and $8 \mu \mathrm{M}$ BAP. However, induction of axillary bud sprout as in the case of unrooted shoot was observed. Success was not achieved even when the concentration of NAA and BAP was increased to $1.8 \mu \mathrm{M}$ NAA and $24 \mu \mathrm{M}$ BAP. In all the concentrations, axillary bud sprout was observed though significantly less than those achieved on $0.6 \mu \mathrm{M}$ NAA and $8 \mu \mathrm{M}$ BAP. Success was achieved when plantlets were subcultured in $2.4 \mu \mathrm{M}$ NAA and $32 \mu \mathrm{M}$ BAP, 8 hours photoperiod and $1 / 2$ strength of MS medium. On $2.4 \mu \mathrm{M}$ NAA and $32 \mu \mathrm{M}$ BAP and 6-16\% sucrose supplemented with full strength MS medium and 16 hours photoperiod, browning of leaves and stems was observed consequently the plantlets died. On $1 / 2$ strength MS medium, induction of microrhizomes was observed within 2 weeks. Increase in average fresh weight and average number of rhizomes was observed as the concentration of sucrose increased. Microrhizomes formed in 10\% sucrose supplemented media were found to be largest in size with highest average fresh weight of $5.12 \pm 0.11 \mathrm{~g}$ and with $2-3$ eyes (Tab. 6, Fig. $1 \mathrm{~g}$ ). The microrhizomes from shoot tip culture plantlets were more matured and larger after 8 weeks, than those transferred from axillary bud culture. Microrhizomes were harvested after 8 weeks, and were transferred to river sand and cow dung mixture (1:1) filled in earthen pots, they sprouted into $2-4$ shoots after 2 weeks of ransplantation and grew to complete plants within 5 weeks. The microrhizomes showed 90\% survival.

\section{Acclimatization}

The plantlets acclimatization is carried out by transferring the plantlets to potting mixture containing river sand and cow dung mixture $(1: 1)$ and survival touches about $85 \%$.

\section{Discussion}

In the natural habitat, the axillary buds of Costus species are usually dormant. There has been no report on nodal segment culture of Costus pictus. However, nodal segment culture have been reported in numerous tree species like Wrightia tomentosa (Purohit et al., 1994), Azadiracta indica (Arya et al., 1995) and also in bamboo species like Dendrocalamus longispathus (Saxena and Bhojwani, 1993) and D. giganteus (Ramanayake and Yakandawala, 1997). The present studies have shown that cutting the stem to segments and culturing them on medium supplemented with suitable PGRs can break the dormancy of the bud. Literature surveys have revealed many possible reason. According to Pilate et al. (1989), auxin make the shoot apex a sink for cytokinin from the roots and decapitation increases the accumulation of cytokinin in axillary bud. Langridge 
et al. (1989) demonstrated with transgenic plant that contained the genes for bacterial luciferase (LUX A and LUX $B$ ), under the control of an auxin responsive promoter that auxin content of the axillary bud increases after shoot apex were decapitated. During this experiment, it was observed that bud-break frequency was higher in stem which have flowered and in nodal segment from upper portion of the stem. The completion of flowering may have led to distribution of PGRs and nutrient towards axillary buds and may be the upper portion of stem has lower level of $A B A$. It has already been reported that decapitation of flowering apex promoted outgrowth of axillary buds (McDaniel, 1996). Pearce et al. (1995) have also reported in Flytrigia repens (Quackgrass) that ABA level which is usually high in dormant lateral buds, declined to $20 \%$ of control level within 24 hours after the rhizomes are decapitated.

Hence, it is possible to break bud-dormancy in cultured nodal segment due to decapitation of shoot apex and rhizomes. In the present investigation also, the dormancy of in vitro axillary buds are broken when shoot apex has been decapitated from stems. These in vitro axillary bud sprouts can be used as explants for shoot multiplication instead of collecting stems from natural habitats.

It has already been reported that the nodal segments of Costus speciosus show bud-break and shoot multiplication in medium supplemented with BAP, NAA and AdS (Punyarani and Sharma, 2009). In the present investigation, both bud-break and shoot multiplication is possible in media supplemented with BAP and NAA. The propagules of Costus pictus also produce higher average number of multiple shoot in comparison to propagules of Costus speciosus (Punyarani and Sharma, 2009). However, in both Costus pictus and Costus speciosus, the optimal sucrose concentration for shoot multiplication is 5\% sucrose. The axillary bud of Costus speciosus were rooted during bud-break and shoot multiplication experiment in medium supplemented with AdS in conjunction with BAP and NAA. Hence, additional treatment was not required for root induction (Punyarani and Sharma, 2009). However, for Costus pictus the shoots are required to be transferred to medium supplemented with 1-12 $\mu \mathrm{M}$ NAA or IAA and $8 \mu \mathrm{M}$ BAP for root induction.

Nodal segment provides an alternative source of in vitro propagation in Costus species. It overcomes many disadvantages of using rhizomatous eye as an explants. The main disadvantage of using rhizomatous eyes are that the uprooted rhizomes usually fail to survive after rhizomatous eyes are decapitated and establishment of in vitro culture is usually difficult due to higher contamination (Balachandran et al., 1990). In nodal segment culture, the rhizomes are not uprooted, contamination was less, matured stem which have flowered was used and one matured stem usually contained 15-20 axillary buds in comparison to 4-5 rhizomatous eye in one rhizome.

Assimilate partitioning from source to sink is essential for the harvestable component of economically impor- tant plants (Farrar, 1992; Wardlaw, 1990). The harvestable yield is the result of carbon dioxide fixation and the subsequent allocation of fixed carbon and assimilates into economically important component.

For Zingiberales, rhizomes are the harvestable organ of economic importance. Rhizomes serve as sink where assimilates are unloaded. In the present investigation, plantlets of Costus pictus produce rhizome in $1 / 2$ strength MS medium enriched with $2.40 \mu \mathrm{M}$ NAA and $32 \mu \mathrm{M}$ BAP and lower photoperiod of $8 \mathrm{hr}$ illumination. Several workers have reported importance of photoperiod, in addition to sucrose and temperature. Role of photoperiod in in vitro induction of tuber have been reported in potato (Hussay and Stacey, 1984) and tulip (Taeb and Anderson, 1990). In vitro microrhizomes of ginger plantlets were produced in MS medium enriched with 3\% sucrose and incubated in higher light intensities at 9000 Lux of continuous illumination (Sakamura et al., 1986). It is apparent that active photosynthesis under this condition may have provided the required energy for rhizome formation. The same energy when supplied as sucrose ( $9 \%$ or $12 \%$ ), ginger plantlets produced rhizomes irrespective of variations in photoperiod in ginger (Bhat et al., 1994). However, turmeric plantlets cultured in $8 \%$ sucrose with lower concentration of growth hormone supplement and lower photoperiod of $8 \mathrm{hr}$ illumination produced rhizomes (Sunitibala et al., 2001). In Costus pictus, the plantlets cultured under 16 hours illumination and full strength MS medium, 0.6 $\mu \mathrm{M}$ NAA, $7 \mu \mathrm{M}$ BAP and 5-13\% sucrose showed small rhizomes and induction of axillary bud sprout. The size of rhizomes increased when photoperiod was reduced to 8 $\mathrm{hr}$, concentrations of BAP and NAA are increased to 32 $\mu \mathrm{M}$ and $2.4 \mu \mathrm{M}$ respectively, MS medium $1 / 2$ strength but same sucrose concentration. Therefore, it may be safely inferred that plantlets of Costus pictus produce rhizomes under stressful condition of low photoperiod, supra-optimal concentration of PGRs, $1 / 2$ strength MS medium and higher sucrose concentration. Hence, Costus pictus plantlets produce microrhizome when activation energy is provided in such a way that it is not conducive for axillary bud sprout.

\section{References}

Arya S, Rathore TS, Arya ID (1995). In vitro propagation of neem from seedling and mature tree. Ind J Plant Genet Res $8(2): 247-252$

Balachandran SM, Bhatt SR, Chandel KPS (1990). Clonal multiplication of turmeric (Curcuma spp) and ginger (Zingiber officinale Rosc.). Plant Cell Rep 8:521-524.

Bhat SR, Chandel KPS, Kacker A (1994). In vitro induction of rhizomes in ginger, Zingiber officinale Roscoe. Ind J Exptl Biol 32:340-344.

Sunitibala H, Damayanti M, Sharma GJ (2001). In vitro propagation and rhizome formation in Curcuma longa Linn. 
78

$$
\text { Cytobios 105:71-82. }
$$

Chaturvedi HC, Misra P, Jain M (1984). Proliferation of shoot tips and clonal multiplication of Costus speciosus in longterm culture. Plant Sci Letts 35:67-71.

Farrar JF (1992). The whole plant: carbon partitioning during development, 163-179 p. In: Pollock CJ et al. (Eds.). Carbon Partitioning within and between Organisms. BIOS Scientific Publishers, Oxford.

Geerish G, Thomas SK, Joseph B, Paulose CS (2009). Antihyperglycemic and insulin secretory activity of Costus pictus leaf extract in streptozotocin induced diabetic rats and in vitro pancreatic islet culture. J Ethnopharmacol 123(3):470-474.

George A, Thankamma A, Devi R, Fernandez A (2007). Phytochemical investigation of insulin plant. As J Chem 19:3427-3430.

Hussay G, Stacey NJ (1984). Factors affecting the formation of in vitro tubers of potato (Solanum tuberosum L.). Ann Bot 53:565-578.

Jayasri MA, Radha A, Mathew TL (2009). $\alpha$-amylase and $\alpha$-glucosidase inhibitory activity of Costus pictus D. Don in the management of diabetes. J Herb Med Toxicol 3(1):9194.

Joshi SG (2000). Medicinal Plants. Oxford and IBH Publishing Co., New Delhi, 190 p.

Kirchoff BK, Rutishauser R (1990). The phyllotaxy of Costus (Costaceae). Bot Gaz 151:88-105.

Kress WJ (1990). The phylogeny and classification of the Zingiberales. Ann Missouri Bot Gard 77:698-721.

Kress WJ (1995). Phylogeny of the Zingiberaceae: morphology and molecules, 443-460 p. In: Rudall P, Cribb PJ, Cutler DF, Humphries CJ (Eds.). Monocotyledons: Systematics and Evolution, Royal Botanic Gardens, Kew.

Kress WJ, Princ LM, Hahn WJ, Zimmer EA (2001). Unraveling the evolutionary radiation of the families of the Zingiberales using morphological and molecular evidence. Syst Biol 50:926-944.

Langridge WHR, Fitzgerald KJ, Koncz C, Schell J, Szalay AA (1989). Dual promoter of Agrobacterium tumefaciens mannopine synthase genes is regulated by plant growth hormones. Proc Natl Acad Sci USA 86:3219-3223.

Malabadi RB, Mulgand GS, Nataraja K (2005). Effect of triacotanol on the micropropagation of Costus speciosus (Koen.) Sm. using rhizome thin sections. In vitro Cell Dev Biol Plant 41:129-132.
McDaniel C N (1996). Developmental physiology of floral initiation in Nicotiana tabacum. J Exptl Bot 45:465-475.

Murashige T, Skoog F (1962). A revised medium for rapid growth and bioassaya with tobacco tissue culture. Physiol Planta 15:473-497.

Pearce DW, Taylo JS, Robertson JM, Harker KN, Daly EJ (1995). Changes in abscissic acid and indole-3-acetic acid in axillary buds of Elytrigia repens released from apical dominance. Physiol Planta 94:110-116.

Pilate G, Sotta B, Maldiney R, Jacques LM, Sossountzov Miginiac E (1989). Absccisic acid, IAA and cytokinin changes in buds of Pseudotsuga menziesii during bud quiescence release. Physiol Planta 76:100-106.

Punyarani K, Sharma GJ (2009). Micropropagation of Costus speciosus (Koen) Sm. using nodal segment culture. Not Sci Biol 2(1):58-62.

Purohit SD, Kukda G, Sharma P, Tak K (1994). In vitro propagation of an adult tree Wrightia tomentosa through enhanced axillary branching. Plant Sci 103:67-72.

Ramanayake SMSD, Yakandawala K (1997). Micropropagation of the gaint bamboo (Dandrocalamus gigangteus Munro.) from nodal segments taken from field grown culms. Plant Sci 129:213-223.

Sakamura F, Ogohara K, Suga T, Taniguchi K, Tanaka R (1986). Volatile constituents of Zingiber officinale rhizome produced in vitro shoot-tip culture. Phytochem 25:1333-1336.

Saxena S, Bhojwani S (1993). In vitro clonal multiplication of 4 year-old plants of the bamboo, Dendrocalamus longispathus Kurz. In vitro Cell Devl Biol Plant 29:134-142.

Shilpa K, Sangeetha KN, Muthusamy VS, Sujatha S, Lakshmi BS (2009). Probing key targets in insulin signaling and adipogenesis using a methanolic extract of Costus pictus and its bioactive molecules, methyl tetracosonoate. Biotechnol Letts 31(12):1837-1841.

Specht CD (2006). Systematics and evolution of the tropical monocot family Costaceae (Zingiberales): a multiple dataset approach. Syst Bot 31:88-105.

Specht CD, Kress WJ, Stevenson DW, DeSalle R (2001). A molecular phylogeny of Costaceae (Zingiberales). Molec Phylog Evol 21:333-345.

Taeb AG, Anderson PG (1990). Effect of photoperiod and quality of light on bulbing of tulip shoots regenerated in vitro. J Hort Sci 65:71-74.

Wardlaw IF (1990). The control of carbon partitioning in plants. New Phytol 116:341-381. 